\author{
St ud i a P ilosophic a \\ Wrat i s l a vi e n s i a \\ vol. XV, fasc. $2(2020)$ \\ https://doi.org/10.19195/1895-8001.15.2.14
}

\author{
STANISŁAW ŁOJEK \\ ORCID: 0000-0001-6670-0518 \\ Uniwersytet Jagielloński
}

\title{
Tworzenie siebie i wolność. Myśl etyczna Foucaulta
}

\section{Making Themselves and Freedom. Foucault's Ethical Thought}

\begin{abstract}
In the later phase of his work, Foucault was particularly interested in exploring the possibilities of creating our own subjectivity and presenting its ethical dimension. The notion of pastoral power as well as the distinction between morality focused on ethics and morality focused on a normative code played a significant role in this undertaking. The former turned out to be particularly important in the context of Foucault's earlier findings, according to which, a subject is a social construct, a product of regimes of power/knowledge. This was because pastoral power, although like any other kind of power it forms us from outside, strongly implies an active participation of the subject in the creation of himself. This kind of activity dominated also in morality focused on ethics which, according to Foucault, was practised by the Greco-Roman elites (above all in the first centuries of our era). In my text, I analyse the above themes in an attempt to show that in Foucault's works they constitute the emancipation project of "new" morality.
\end{abstract}

Keywords: Foucault, subject, power, pastoral power, ethics, care for oneself, aesthetics of existence

Nie istnieje suwerenny, źródłowy podmiot, żadna uniwersalna, wszędzie taka sama forma podmiotu. [...] Podmiot jest konstytuowany poprzez praktyki ujarzmiania lub też, w bardziej autonomiczny sposób, poprzez praktyki uwalniania się, praktyki wolności, tak jak w starożytności, oczywiście w oparciu o szereg reguł, stylów i innowacji, które znajdują się w środowisku kulturowym¹.

${ }^{1}$ M. Foucault, An Aesthetics of Existence, [w:] Politics, Philosophy, Culture: Interviews and Other Writings, 1977-1984, L. Kritzman (red.), London 1988, s. 50; jeśli nie podano inaczej, tłum. S.Ł. 
Michel Foucault zawsze był wielce krytyczny wobec ,kartezjańskiej” idei podmiotowości, dominującej jego zdaniem w świecie zachodnim, wedle której podmiot jest stałą, uniwersalną podstawą, autonomicznym centrum ludzkiego poznawania oraz działania ${ }^{2}$. Zawsze też interesowało go odkrywanie i badanie rozmaitych sposobów, mechanizmów konstytuowania (oraz i konstytuowania się) podmiotu:

Warto byłoby spróbować ustalić, w jaki sposób doszło do ukonstytuowania podmiotu, który nie jest ostatecznie dany, nie jest rzeczą, na podstawie której prawda wydarza się dziejom, lecz raczej podmiotem, który konstytuuje się w obrębie dziejów i jest przez dzieje ustawicznie ustanawiany oraz przekształcany. Właśnie ku takiej radykalnej krytyce podmiotu powinny zmierzać nasze starania ${ }^{3}$.

W latach siedemdziesiątych, po przeprowadzeniu badań do pracy Nadzorować $i$ karać, Foucault argumentuje, że podmiot jest produktem władzy (a dokładniej: reżimów władzy/wiedzy $)^{4}$. Mówi

o istnieniu szeregu dziejowo zmiennych reżimów władzy/wiedzy, które są z sobą niewspółmierne i z których każdy podtrzymuje odmienny typ podmiotowości. Wszelka wiedza wyrasta z systemu władzy: reżimy władzy określają, jaka wypowiedź jest sensowna, jakie kwestie powinny być badane, jakie fakty mają być tworzone itd. Ale w równym stopniu wszystkie reżimy władzy są konstytuowane przez formacje dyskursywne: reżimy wiedzy określają między innymi, kto posiada, a kto nie, intelektualny autorytet, by decydować w poszczególnych kwestiach oraz to, w jaki sposób, o kim i przez kogo powinny być gromadzone informacje. Władza i wiedza zawsze się wzajemnie implikują: zawsze wspólnie przenikają wspólnie określone reżimy, będące źródłem sposobów ujarzmiania, oraz wyzwalania, poprzez które podmioty się konstytuują ${ }^{5}$.

To zatem społeczeństwo, ujmowane w kategoriach różnorodnych (historycznie i geograficznie zmiennych) reżimów wiedzy/władzy, definiuje oraz kształtuje naszą podmiotowość. Jest ono bowiem źródłem zarówno norm, wedle których staramy się żyć, jak i praktyk, które prowadzenie takiego życia umożliwiają. Jesteśmy arbitralnym konstruktem społecznego modelowania. Foucault uważa jednak, że uświadomienie sobie tego nie powinno skłaniać nas do fatalistycznej rezygnacji. Przeciwnie, jego zdaniem jest ono wstępnym warunkiem osiągnięcia tego rodzaju wolności, która w naszych czasach jest najistotniejsza — wolności od narzuconej nam i krepującej naszą indywidualność tożsamości ${ }^{6}$. Ale uwolnienie się od niej stanie się możliwe jedynie wtedy, gdy sami zdołamy stworzyć siebie na nowo.

O tym, że taka twórczość, przekształcanie własnego istnienia w dzieło sztuki, jest możliwa, świadczy zdaniem Foucaulta przykład Greków, szczególnie z okresu hellenistycznego ${ }^{7}$. Badaniem tej możliwości, również w kontekście wykorzystania jej w czasach współczesnych, zajmował się przede wszystkim w latach osiemdziesiątych. Mogłoby się wydawać, iż stoi ona w sprzeczności z jego wcześniejszymi ustaleniami na temat konstytuowania podmiotu przez reżimy wiedzy/władzy. Ale

\footnotetext{
${ }^{2}$ Ibidem.

${ }^{3}$ M. Foucault, Truth and Juridical Forms, [w:] idem, Power, J.D. Faubion (red.), London 2001, s. 3.

${ }^{4}$ M. Foucault, Two Lectures, [w:] idem, Power/Knowledge: Selected Interviews and Other Writings 1972-1977, C. Gordon (red.), Brighton 1980.

${ }^{5}$ M. Bevir, Foucault and Critique: Deploying Agency against Autonomy, „Political Theory” 27 [1]

${ }^{6}$ M. Foucault, Subject and Power, [w:] idem, Power..., s. 216.

${ }^{7}$ M. Foucault, An Aesthetics..., s. 49.
} (1999), s. 66. 
on sam pokazuje w nich, że nadanie pożądanego (z punktu widzenia owych reżimów) kształtu naszym tożsamościom wymaga od nas współuczestnictwa (na przykład w postaci internalizacji narzucanych norm). W późniejszym okresie twórczości właśnie ten aspekt budzi jego szczególne zainteresowanie. Zauważa, iż szczególnie doniosłą rolę odgrywa on w działaniu pewnego typu władzy, nazywanego przezeń „władzą pastoralną", który jego zdaniem miał decydujący udział w konstytuowaniu dominującej współcześnie formy podmiotowości. Określony stosunek podmiotu do samego siebie oraz praktyki, dzięki którym jest on w stanie odpowiednio kształtować siebie, maja dla tej władzy kluczowe znaczenie. Dla Foucaulta jest ona interesująca również z tego względu, że praktyki owe, a przynajmniej ich część, były wcześniej wykorzystywane przez starożytnych Greków i Rzymian do nadawania indywidualnego, wyjątkowego kształtu własnemu istnieniu. Władza pastoralna przejęła je, ale też przekształciła odpowiednio do własnych celów.

Działanie władzy pastoralnej zmierza do tego, by wszyscy członkowie „stada" żyli i postępowali wedle takich samych norm i zasad. Pożądany kształt podmiotowości, będący efektem stosowania wspomnianych praktyk, musi więc być zasadniczo odmienny od tego, czego oczekiwali od nich Grecy — nie pragnie się wyjątkowości, lecz normalizacji, nie dzieła sztuki, lecz kopii naśladującej uniwersalny model. Zdaniem Foucaulta jest niezmiernie istotne, że te same, lub podobne, praktyki moralne mogą służyć różnym celom oraz że jednym z nich może być tworzenie siebie. Równie istotne jest to, że różnym celom mogą służyć te same, lub podobne, normy i zasady moralne. Grecy praktykujący „estetykę istnienia” nie odrzucali bowiem norm, lecz wręcz przeciwnie - traktowali je bardzo restrykcyjnie. Ale ich stosunek do nich był oczywiście znacząco odmienny od tego, jaki charakteryzuje na przykład działanie władzy pastoralnej.

W Historii seksualności Foucault wprowadza rozróżnienie między moralnością ukierunkowaną na etykę a moralnością ukierunkowaną na kodeks, które pozwala mu bardziej precyzyjnie określić opisaną wcześniej „elastyczność” norm oraz praktyk moralnych. Podkreśla on, że choć system moralny zawsze zawiera oba elementy („etykę” oraz „kodeks"), w poszczególnych jego typach mogą być one odmiennie akcentowane. Ta obserwacja służy mu między innymi do sformułowania wniosku, że moralność inna od tej, którą uważamy za jedynie właściwą, moralność ukierunkowana na estetykę istnienia, jest możliwa. Foucault uważa, iż mogłaby to być odpowiedź na dzisiejszy kryzys moralny, który jego zdaniem wiąże się z narastającą świadomością wyczerpania się dotychczasowej moralności. Jednak zasadniczym dla niego powodem przeprowadzania tych i wielu innych analiz pozostaje poszukiwanie odpowiedzi na dwa powiązane z sobą pytania: „kim jesteśmy?”, „kim możemy się stać?”. Albo też (co na jedno wychodzi): „co nas więzi?”, „,o mogłoby być obietnicą wyzwolenia?”.

\section{I}

Niemal we wszystkich swoich pracach Foucault zajmował się badaniem kolejnych etapów oraz rozmaitych aspektów kształtowania naszej podmiotowości przez władzę/wiedzę. Badania te pozwoliły mu sformułować zasadniczą tezę dotyczącą 
relacji między podmiotowością a władzą - indywidualne podmioty nie są atomami, na które władza oddziałuje, podporządkowując je sobie, lecz są przez władzę konstytuowane ${ }^{8}$. Zwięzły opis mechanizmów podmiototwórczego działania owych reżimów odnajdziemy w wykładzie z 1974 roku, w którym omawia on proces formowania się, w końcu XVII i początku XIX wieku, ,społeczeństwa dyscyplinar-

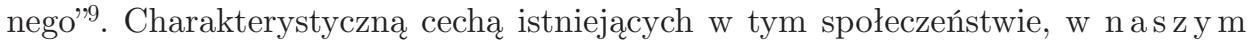
społeczeństwie, relacji władzy jest według niego „panoptycyzm”. Tym mianem określa on rodzaj władzy, która ,,jest stosowana wobec jednostek w postaci ciągłego indywidualnego nadzoru, w postaci kontroli, kary i rekompensaty, oraz w postaci korygowania, czyli modelowania i przekształcania jednostek wedle określonych norm"10. W nowoczesnych społeczeństwach, twierdzi Foucault, egzystencja każdej jednostki jest uwięziona w instytucjonalnej sieci sekwestracji. Sieć tę tworzą zarówno instytucje państwowe, jak i niepaństwowe (pedagogiczne, medyczne, karne czy przemysłowe), których celem jest sprawowanie kontroli i branie odpowiedzialności za nasze ciała oraz dusze przez niemal cały czas naszego istnienia. Przy czym, aby należycie wypełniać te funkcje, instytucje muszą dysponować dwojakiego rodzaju wiedzą: pochodzącą od każdej z jednostek wiedzą o sobie oraz obiektywną wiedzą o jednostkach ${ }^{11}$.

Efektem długotrwałego oddziaływania podmiototwórczych i socjalizujących zarazem procesów kształtowania jest normalizacja, która zawęża i zubaża możliwości ludzkiego istnienia, sprowadzając to, co indywidualne, do tego, co zgodne z normą, takie samo u wszystkich, i z tego względu uznawane za uniwersalne oraz konieczne. To, co dokonywało się w imię postępu racjonalności, moralności i wolności, okazało się specyficzną formą zniewolenia, czy, jak to ujmuje Foucault: ujarzmienia. Tym, co nas ujarzmia, jest nasze własne ,ja”, które jawi się jako prawdziwa tożsamość, a które w rzeczywistości zostało ukonstytuowane w przygodnościowy sposób przez rozmaite aparaty normalizacji.

Foucault uważa, iż uświadomienie sobie tego stanu rzeczy powinno skłonić nas do odmowy uznania tego, czym jesteśmy, do uwolnienia się od narzucanej nam od wieków formy podmiotowości poprzez stworzenie własnej, wyjątkowej indywidu-

${ }^{8}$ M. Foucault, Society must be defended, tłum. D. Macey, New York 2003, s. 29-30. Leslie Paul Thiele przedstawia te relacje w szerszym kontekście, nawiązując do słynnej tezy Foucaulta o ,śmierci człowieka”: „Dusza człowieka, sam człowiek, nie jest transcendentalną esencją, która nieustannie stawia opór i przeciwko której władza nieustająco walczy. Człowiek nie jest autonomicznym podmiotem, przeciwko któremu władza stosuje swoje fortele i techniki, nie jest niezmiennym podmiotem, zmagającym się z władzą, która w trakcie tych zmagań nigdy nie przenika jego istnienia. Człowiek jest raczej wytworem tychże technik i forteli. Analizy Foucaulta nie ujawniają Człowieka, transcendentalnego podmiotu, który pozostaje niezmienny pod gęstymi sieciami władzy. Jest raczej tak, że Foucault wydobył na jaw konstytuowanie samego Człowieka, historycznego wytworu mechanizmów władzy. [...] Stąd śmierć Człowieka: tak jak Człowiek został wytworzony, tak zmarł. Człowiek transcendentalny podmiot, Człowiek podmiot antropologii" - L.P. Thiele, Foucault's Triple Murder and the Modern Development of Power, „Canadian Journal of Political Science / Revue canadienne de science politique” 19 [2] (1986), s. 251.

${ }^{9}$ M. Foucault, Truth and Juridical..., s. 54.

10 Ibidem, s. 70.

11 Ibidem, s. 79 n. 
alności ${ }^{12}$. Jednak w świetle jego własnych opisów przekształcania istot ludzkich w podmioty zarówno wspomniana odmowa, jak i promowanie nowych form podmiotowości mogą wydawać się niemożliwe do zrealizowania. Jeśli bowiem jesteśmy bez reszty produktem społecznych praktyk, to jak moglibyśmy wynaleźć, albo tylko odkryć, praktyki oraz dyskursy wyrażające to, co w nas najbardziej własne? Co więcej, mimo iż praktyki te są dziejowo zmienne, to jednak te, które charakteryzują daną epokę i dane społeczeństwo (choćby te, w których przyszło nam żyć), całkowicie w nich dominują, przenikając i określając wszystkie dziedziny ludzkiego życia. Jak zatem uwolnić się od ich wpływu, jakim językiem i w odniesieniu do jakich norm czy wartości opisać się na nowo? Można odnieść wrażenie, iż dokonana przez Foucaulta analiza działań wiedzy/władzy ukazuje będącą przedmiotem tych działań jednostkę jako bezwiedne tworzywo, beznadziejnie uwięzione w nadawanej z zewnątrz formie.

Z drugiej jednak strony, o skuteczności dyscyplinującej władzy w nadawaniu jednostkom pożądanego kształtu decyduje możliwość oddziaływania na ich wnętrza. Celem stosowania rozmaitych technik władzy jest osiągnięcie stanu, w którym jednostka sama czuwa nad tym, by jej myślenie, odczuwanie i postępowanie były zgodne z normą. Zdaniem Foucaulta władza najlepiej osiagga swoje cele, gdy działanie ulega uwewnętrznieniu, a sama pozostaje niewidzialna. Owszem, nasza podmiotowość jest rezultatem działania rozmaitych sił i relacji wiedzy/władzy, ale prawdą jest również, że sami aktywnie uczestniczymy w nadawaniu jej kształtu.

W latach osiemdziesiątych Foucault podkreślał, iż analizowanie procesów obiektywizowania podmiotu jest niewystarczajace i że trzeba je uzupełniać badaniem „technik siebie”, czyli sposobów, w jakie poszczególni ludzie sami siebie przekształcają w podmioty ${ }^{13}$. We wcześniejszych pracach, takich jak Nadzorować i karać, zajmował się przede wszystkim władzą dyscyplinująca, która oddziałuje bezpośrednio na ciało (choć pośrednio na duszę) i narzuca nam tożsamość z zewnątrz. Teraz natomiast uznał, że choć dokonane tam ustalenia pozostają w mocy, należałoby zbadać również takie relacje władzy, które w większym stopniu zakładają właśnie samokształtowanie się podmiotu. Jego zdaniem są one szczególnie istotne w specyficznych technikach władzy, które są ukierunkowane na jednostki i przeznaczone do „rządzenia nimi w ciągły i notoryczny sposób”"14. Techniki te odgrywają szczególną rolę w funkcjonowaniu władzy państwowej, będącej według Foucaulta nową polityczną formą władzy, która od XVI wieku podlega nieustannemu rozwojowi ${ }^{15}$. Rozwój ten, jak się wydaje, zmierza do coraz większej centralizacji, a państwo ma na względzie przede wszystkim interes ogółu. Jednak zdaniem Foucaulta jest tylko jedna strona medalu, gdyż władza państwowa jest władzą, która totalizując, jednocześnie indywidualizuje, w której oba te trendy są z sobą splecione i wzajemnie zależne ${ }^{16}$. Ich współoddziaływanie decyduje o skuteczności

12 M. Foucault, Subject and Power..., s. 216.

13 Ibidem.

${ }^{14}$ M. Foucault, „Omnes at singulatim”: przyczynek do krytyki politycznego rozumu, tłum. D. Leszczyński, L. Rasiński, [w:] idem, Filozofia, historia, polityka. Wybór pism, Warszawa 2000, s. 221.

15 M. Foucault, Subject and Power..., s. 213.

16 Ibidem. 
i trwałości tej formy politycznej władzy. I to właśnie ono jest odpowiedzialne za ukształtowanie współczesnej formy podmiotowości. Rozpoznanie i zrozumienie obu rodzajów technik władzy, totalizujących i indywidualizujących, wydaje się zatem niezbędne do uświadomienia sobie, kim się staliśmy. Zdaniem Foucaulta jest to również konieczne do dostrzeżenia i wykorzystania możliwości uwolnienia się od narzuconej nam jaźni i przekształcenia jej w coś autentycznie naszego.

Techniki indywidualizujące, nakierowane na jednostkę, Foucault nazywa „władzą pastoralną", twierdząc, iż państwo przejęło je, nadając im nowy kształt, odmienny od dawnych technik władzy stosowanych w instytucjach chrześcijańskich ${ }^{17}$. Chrześcijaństwo z kolei wykorzystywało w nich przekształcone i przystosowane do własnych celów praktyki, które w hellenistycznej Grecji stanowiły integralną część „troski o samego siebie"18. Omawiając ten typ władzy ${ }^{19}$, zwraca on uwage, z jednej strony, na jej odmienność od tego, co charakteryzowało wcześniejszą, grecką myśl i praktykę polityczną, z drugiej zaś - na zastosowanie (po zmodyfikowaniu) jej mechanizmów przez instytucje nowożytnego państwa. Stwierdza, iż zachodnie społeczeństwa, które pojawiły się pod koniec okresu starożytnego i które ,wymyśliły wielką liczbę różnych form politycznych i kilkakrotnie gruntownie zmieniały swe struktury prawne”, jako jedyne ,rozwinęły osobliwą technikę władzy, traktującą olbrzymią większość ludzi jako stado z kilkoma pasterzami. To one ustanowiły w ten sposób między ludźmi serie złożonych, stałych i paradoksalnych relacji”20. Dla nas najbardziej interesujące są te relacje, które dotyczą kształtującego oddziaływania pastoralnej władzy na poszczególne jednostki.

\section{II}

Właściwą rolą chrześcijańskiego pasterza jest kierownictwo i pomoc w osiągnięciu przez członków stada zbawienia. Ze względu na specyfikę owego celu konieczne jest, by troska pasterza była zindywidualizowana i permanentna ${ }^{21}$. Takie samo - celowe, stałe i zindywidualizowane - jest także posłuszeństwo każdej jednostki, członka stada, wobec pasterza ${ }^{22}$. Zdaniem Foucaulta osobisty charakter więzi między troszczącym się pasterzem a posłusznym mu członkiem stada bodaj najwyraźniej odróżniał chrześcijańskie duszpasterstwo od myśli greckiej:

Jeśli Grek musiał być posłuszny, godził się z tym, ponieważ takie było prawo bądź wola jego miasta. Jeśli przypadkiem podążał za wolą jakiejś szczególnej osoby (lekarza, mówcy, nauczyciela), znaczyło to, że osoba ta racjonalnie przekonała go do takiego postępowania. [...] Dla chrześcijaństwa więź z pasterzem jest czymś indywidualnym, osobistym posłuszeństwem wobec niego. Jego wolę spełnia się nie dlatego, że jest zgodna z prawem, i nie na tyle, na ile jest z nim zgodna, lecz przede wszystkim dlatego, że jest to jego wol a ${ }^{23}$.

\footnotetext{
17 Ibidem.

18 M. Foucault, „Omnes at singulatim”..., s. 229.

19 Przede wszystkim w: ibidem, s. 224 n.; oraz M. Foucault, Subject..., s. 213-215.

20 M. Foucault, „Omnes at singulatim”..., s. 224.

21 Ibidem, s. 223.

22 Ibidem, s. 230.

${ }^{23}$ Ibidem.
} 
Władza pastoralna jest więc władzą nad ,żywymi jednostkami”, w odróżnieniu od władzy politycznej, która jest sprawowana nad „prawnymi podmiotami”24 . Zdaniem Foucaulta, aby zrozumieć mechanizmy funkcjonowania władzy oraz rolę, jaką odgrywa ona w kształtowaniu podmiotowości, należy uważnie przyjrzeć się kwestiom związanym z przenikaniem się i wzajemnym wspieraniem obu jej wymienionych rodzajów. Przy czym uważa on, że ich specyficzne współoddziaływanie wywierało wpływ na całe dzieje Zachodu oraz że nadal pozostaje dla nas niezmiernie istotne $^{25}$. Dzisiejsze państwo opiekuńcze, powiada, opiera się wprost na zasadzie, że życie jednostek jest przedmiotem działania władzy, której powszechnie akceptowaną rolą jest „zapewnianie, wspieranie i polepszanie życia każdego i kogokolwiek" ${ }^{\prime 2}$. Jest to ta sama rola, jaką władza odgrywała w instytucjach chrześcijańskich, choć oczywiście wspieranie i polepszanie życia instytucje te rozumiały inaczej.

Ponieważ chrześcijański pasterz troszczył się nade wszystko o to, by każdy członek stada był w stanie osiągnąć zbawienie, interesowało go nie tylko życie każdego jako takie, lecz również, i przede wszystkim, poszczególne czyny, uczucia oraz myśli. Wszystkie one miały być rozpatrywane z moralnego punktu widzenia: jako pożądane i godne potępienia, dobre i złe. Aby móc należycie wypełniać swoje zadanie, pasterz musiał wejść w posiadanie specyficznej wiedzy, wiedzy zindywidualizowanej, dotyczącej nie całego stada, lecz poszczególnych jednostek. Wiedza ta, jak zauważa Foucault, ma trojaki charakter:

Pasterz musi być zaznajomiony z materialnymi potrzebami każdego członka stada i w razie konieczności je zaspokajać. Musi wiedzieć, co się dzieje, co każdy z nich robi — znać jego grzechy publiczne. I na koniec musi wiedzieć, co dzieje się w duszy każdego, tzn. znać jego sekretne grzechy, postęp na drodze do świętości ${ }^{27}$.

Nietrudno zauważyć, że uzyskanie przez pasterza potrzebnej wiedzy wymaga uprzedniego uzyskania jej przez poszczególnych członków stada. Dotyczy to zwłaszcza „prywatnej” duszy każdej jednostki. Wymóg jej poznania spoczywa więc również, i bardziej pierwotnie, na każdym członku stada. Związany z pasterzem więzią stałego i osobistego posłuszeństwa jest on także zobowiązany do dzielenia się z nim uzyskaną przez siebie wiedzą o sobie samym:

Ponieważ w chrześcijaństwie pożądania stały się substancją etyczną, ponieważ ten wymiar jaźni okazał się najbardziej istotny z etycznego punktu widzenia, od chrześcijanina wymagano rozszyfrowywania tychże pożądań, praktykowania „permanentnej hermeneutyki siebie”, wymagającej bardzo „rygorystycznych zobowiązań w odniesieniu do prawdy”. Chrześcijanin powinien nie tylko znać prawdę moralnego życia, lecz również nieustannie badać samego siebie jako pożądający podmiot. [...] Ten nadzór nad samym sobą, niegdyś zarezerwowany dla mnichów, przeniknął do XVI wieku chrześcijańskie społeczeństwo jako całość. [...] Chrześcijaństwo zachęcało do poszukiwania prawdy o własnej jaźni, a poszukiwanie temu służyły złożone praktyki badania sumienia i spowiedzi ${ }^{28}$.

\footnotetext{
${ }^{24}$ Ibidem, s. 229.

${ }^{25}$ Ibidem.

26 Ibidem.

27 Ibidem, s. 231.

28 J. Bernauer, M. Mahon, Michel Foucault's Ethical Imagination, [w:] The Cambridge Companion to Foucault, G. Gutting (red.), Cambridge 2005, s. 153.
} 
Foucault zauważa, że wymienione praktyki były znane już w świecie hellenistycznym jako badanie siebie i przewodnictwo sumienia. Chrześcijaństwo dokonało ich przekształcenia i ściśle z sobą związało:

Z jednej strony, kierowanie sumieniem ustanowiło trwałą więź: owca pozwalała sobą kierować nie tylko, by wyjść cało z jakichś tarapatów — pozwalała sobą kierować w każdej sekundzie. Podlegać kierowaniu to pewien stan i próba ucieczki od niego grozi śmiertelną zgubą. Ten, kto cierpi na brak porady, więdnie jak martwy liść, głosi znana maksyma. Co do badania siebie, jego celem nie było zamykanie się w samoświadomości, lecz umożliwienie jej całkowitego otwarcia się na przewodnika — odsłonięcia przed nim głębi swej duszy ${ }^{29}$.

Jednak najważniejsza przemiana dotyczyła zasadniczego celu stosowania wymienionych praktyk. Dla Greków okresu hellenistycznego było nim uczynienie własnego istnienia czymś tak doskonałym, by mogło stać się przedmiotem afirmacji. Chrześcijanie natomiast badają swą duszę, spowiadają się oraz posłusznie stosują do zaleceń pasterza, aby osiągnąć inne, lepsze istnienie poprzez wyrzeczenie się tego świata i samego siebie ${ }^{30}$.

Niewątpliwie więc chrześcijański podmiot współtworzy własną tożsamość: bada samego siebie, wyznaje oraz odpowiednio kształtuje własne myśli, uczucia i pożądania. Nie możemy jednak zapominać, że owo kształtowanie jest tutaj dostosowywaniem do norm przekazywanych oraz egzekwowanych przez pasterza. Jednostka sprawuje nadzór nad samą sobą w celu osiągnięcia takiego stanu istnienia, które będzie zgodne z określonym pojęciem normalności. Nic dziwnego zatem, że praktyki związane z władzą pastoralną mogły okazać się wielce przydatne również przy formowaniu podmiotów-obywateli nowoczesnego państwa, które zdołało połączyć jednostkową autokontrolę z zewnętrznym nadzorem, opisanym między innymi w Nadzorować i karać: „Nasze społeczeństwa okazały się naprawdę demoniczne, bowiem przypadkowo połączyły ze sobą [...] dwie gry - grę miasto-obywatel oraz gre pasterz-stado - w czymś, co nazywamy nowoczesnymi państwami”31.

\section{III}

Mniej więcej od XVIII wieku, twierdzi Foucault, państwo zaczęło przejmować funkcje właściwe władzy pastoralnej ${ }^{32}$. Celem jej oddziaływania na jednostki nie było już oczywiście osiągnięcie zbawienia w innym świecie. Zostało ono zastąpione przez wiele jak najbardziej ,światowych" celów, takich jak dobrobyt, bezpieczeń-

${ }^{29}$ M. Foucault, „Omnes at singulatim”..., s. 231.

30 Ibidem, s. 232.

31 Ibidem.

${ }^{32}$ M. Foucault, Subject..., s. 214. Jak zauważa Barry Hindess: „W gruncie rzeczy »pastoralne« wykorzystywanie spowiedzi, badania siebie i przewodnictwa napotkać można do dziś nie tylko w chrześcijańskich kościołach i sektach, lecz również w funkcjonowaniu różnych państwowych urzędów, prywatnych charytatywnych i filantropijnych organizacji, w wielu rodzajach doradztwa, terapii i technik modyfikacji osobowości oraz, oczywiście, w praktykach edukacji i szkolenia w rozmaitych publicznych i prywatnych przedsiębiorstwach. W takich przypadkach szkolenie jednoskij w sprawowaniu rządów nad sobą służy jako instrument rządzenia ich zachowaniem" — idem, Filozofie władzy Od Hobbesa do Foucaulta, tłum. D. Leszczyński, L. Rasiński, Warszawa-Wrocław 1999, s. 127. 
stwo czy zdrowie. To z kolei pociągnęło za sobą konieczność zaangażowania w ich realizację wielu, nie tylko państwowych, instytucji. Ostatecznie doprowadziło to do sytuacji, w której należy mówić nie tyle o przenikaniu się i współoddziaływaniu dwóch typów władzy — totalizującej władzy politycznej i indywidualizującej władzy pastoralnej — ile raczej o ,indywidualizującej »taktyce«, która charakteryzuje wielość władz właściwych rodzinie, medycynie, psychiatrii edukacji, pracodawcom"33. Stosowanie owej taktyki polega na rządzeniu jednostkami przy pomocy ich własnej prawdy ${ }^{34}$, które to rządzenie zakłada współudział jednostki w formowaniu samej siebie, w kształtowaniu własnej indywidualności. Błędne jest zatem, stwierdza Foucault, uważanie nowoczesnego państwa za „byt, który rozwinął się ponad jednostkami, ignorując to, czym są, a nawet ich samo istnienie"; przeciwnie, tworzy ono jego zdaniem wielce złożoną strukturę, z którą jednostki „moga być zintegrowane, pod jednym wszakże warunkiem: że ich indywidualności zostanie nadana nowa forma, ukształtowana zgodnie ze zbiorem bardzo specyficznych wzorców"35.

W eseju Subject and Power, z którego pochodzi przytoczony cytat, Foucault wzywa do uwolnienia naszej indywidualności od tak narzuconej formy. Przywołuje również pewien artykuł autorstwa Kanta, w którym usiłując dociec, czym jest nasza teraźniejszość, stawia on pytanie o to, kim jesteśmy ${ }^{36}$. Foucault podkreśla, iż jest ono zasadniczo odmienne od pytania Kartezjańskiego, które zapytywało o podmiot uniwersalny, ahistoryczny ${ }^{37}$. Dla Kanta zrozumienie naszej tożsamości wymaga dokonania krytycznej analizy zarówno nas samych, jak i teraźniejszości: tego historycznego momentu, w którym przyszło nam żyć. Jest to zgodne z ustaleniami wynikającymi z badań samego Foucaulta, które doprowadziły go do wniosku, że społeczeństwo dostarcza nam zarówno wartości, jak i praktyk, wedle których żyjemy.

Kant uważał również, że historyczny moment, w którym przyszło nam żyć i który nosi nazwę oświecenia, stawia nas przed zadaniem osiągnięcia dojrzałości przez takie użycie rozumu, które uwolni go od wszelkiego podporządkowania i sprawi, że będzie posłuszny wyłącznie samemu sobie. Zdaniem Foucaulta zadanie to ciągle jest przed nami, jednak powinniśmy nadać nowy sens postulowanemu przez Kanta krytycznemu badaniu teraźniejszości oraz nas samych:

Krytycznej ontologii nas samych nie należy z pewnością traktować jako teorii, doktryny ani też jako zbioru nagromadzonej wiedzy; należy pojmować ją jako postawę, êthos, filozoficzne życie, gdzie krytyka tego, czym jesteśmy, jest zarazem historyczną analizą narzuconych nam granic i próbą ich przekroczenia $^{38}$.

Wezwanie do przekroczenia granic, nieobecne u królewieckiego filozofa, wynika z uświadomienia sobie, dzięki krytycznej analizie teraźniejszości i nas samych, że

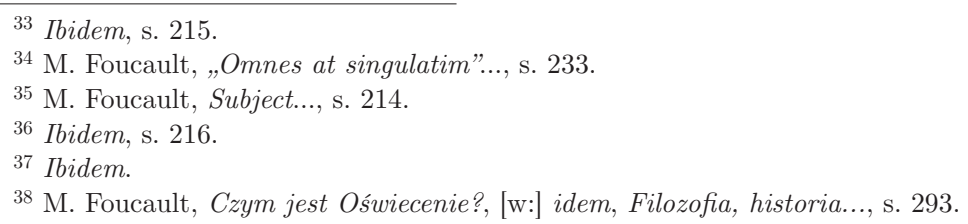


nasza obecna podmiotowość jest znormalizowaną klatka, produktem ujednolicania każdego z nas wedle racjonalnych, uniwersalnych norm. Rozum, który u Kanta miał być narzędziem emancypacji, okazuje się współsprawcą zniewolenia. Osiągnięcie stanu dojrzałości, umożliwiającego autonomiczne używanie rozumu, wymaga zatem uprzedniego uzyskania zdolności do autonomicznego kształtowania tego, kim jesteśmy: „Być może w dzisiejszych czasach celem nie jest odkrycie, lecz odrzucenie tego, czym jesteśmy. Musimy wyobrazić sobie, a następnie stworzyć to, czym moglibyśmy być, aby pozbyć się tego rodzaju politycznego ,podwójnego wiązania", jakim jest

jednoczesne indywidualizowanie i totalizowanie nowożytnych struktur władzy. [...] Polityczny, etyczny, społeczny, filozoficzny problem naszych czasów nie polega na wyzwoleniu jednostki od państwa oraz państwowych instytucji, lecz na wyzwoleniu nas zarówno od państwa, jak i od tego rodzaju indywidualizacji, która jest z państwem związana. Musimy promować nowe formy podmiotowości poprzez odmowę uznania tego rodzaju indywidualności, jaki jest nam narzucany od wielu stuleci ${ }^{39}$.

Nowe formy podmiotowości mogłyby być efektem tego rodzaju twórczości, w której podmiot stwarza sam siebie. W tym celu należałoby wykorzystać między innymi te praktyki, które zostały wprzęgnięte w kształtujące działanie władzy pastoralnej; tym razem jednak nie po to, by dostosować indywidualność do uniwersalnego wzorca, lecz przeciwnie - by nadać jej unikalny kształt. Foucault zauważa, że właśnie w ten sposób były one stosowane w świecie hellenistycznym, gdzie stały się istotnym elementem estetyki istnienia. Jednak po ich przejęciu oraz przekształceniu przez chrześcijańskie instytucje władzy pastoralnej nadano im całkowicie odmienny sens. Badanie siebie oraz przewodnictwo sumienia praktykowano nie po to, by poprzez doskonalenie własnego istnienia dążyć do jego afirmacji, lecz przeciwnie - by wyrzec się siebie w nadziei na inne, lepsze istnienie. Ponieważ oczekiwano - ze względu na specyfikę chrześcijańskiego celu, zbawienia — że każda jednostka, poddana stałemu nadzorowi przewodnika, będzie kształtować sama siebie zgodnie z tym, co uniwersalne, estetykę istnienia zastąpiła jego normalizacja. Między innymi dlatego chrześcijańskie „techniki siebie” mogły zostać wykorzystane, w zmodyfikowanej postaci, przez pastoralną władzę działającą w ramach nowoczesnego państwa.

Foucault uważa, że przejęcie oraz przekształcenie przez chrześcijaństwo antycznych praktyk kształtowania podmiotowości sprawiło, iż zostały one niemal całkowicie zapomniane. Tym samym obca stała się nam idea, że wartości estetyczne powinny przede wszystkim odnosić się do naszego istnienia, że troska o siebie powinna polegać na tworzeniu zeń dzieła sztuki ${ }^{40}$. Teraz jednak wydaje się, iż nawiązanie do tej idei mogłoby umożliwić skuteczne przeciwstawienie się działaniu tej postaci władzy, która narzuca nam i zamyka nas w ujednoliconej formie podmiotowości. Przy czym Foucault stanowczo podkreśla, że naśladowanie Greków

${ }^{39}$ M. Foucault, Subject..., s. 216.

${ }^{40}$ Foucault uważa, że rzeczona idea odradzała się wyłącznie epizodycznie, na przykład w renesansie czy w dziewiętnastowiecznym dandyzmie. Por. M. Foucault, On the Genealogy of Ethics: An Overview of Work in Progress, [w:] H. Dreyfus, P. Rabinow, Foucault: Beyond Structuralism and Hermeneutics, Chicago 1983, s. 362. 
czy Rzymian nie jest dla nas ani możliwe, ani pożądane ${ }^{41}$. Jak pisze Brian Seitz, używa on

grecko-rzymskiego podmiotu jako modelu, który jednak nie ma być propagowany jako gruntująca podstawa ani też kopiowany; który powinien służyć bardziej jako przykład aniżeli ideał. Jako model stoicyzm ucieleśnia alternatywę współczesnego stanu podmiotu, alternatywę proponowaną jako coś, co może przyczynić się do otwarcia nowych konceptualnych oraz egzystencjalnych możliwości. Eksplorując odległą przeszłość i kreśląc w ten sposób kontury podmiotu, którym nie jesteśmy, Foucault poszukuje zasobów dla teraźniejszości w odniesieniu do przyszłości. Przede wszystkim jest jasne, że nie bada on imperialnego podmiotu pierwszych dwóch wieków naszej ery po to, by odnaleźć jakąś „,rzeczywistą prawdę", coś nostalgicznie doskonalszego od anemicznych, lecz przerażających prawd nowożytnego świata $^{42}$.

Nie chodzi zatem o powrót, lecz raczej o ukazanie pewnego, zapomnianego już dzisiaj, ale możliwego, sposobu relacji człowieka z samym sobą. Zdaniem Foucaulta może się ona okazać wiarygodna również dla nas, ponieważ obecnie stajemy przed problemem, który w pewnej mierze podobny jest do tego, z jakim mierzyli się Grecy ${ }^{43}$. Zdołali oni mianowicie stworzyć etykę, w której kształtowanie siebie i związana z nim asceza nie były narzucane ani przez religię, ani przez prawo. W dzisiejszych czasach mamy do czynienia z sytuacją, w której „większość z nas nie wierzy już, że etyka jest ufundowana na religii, i nie chce również, by system prawny ingerował w nasze moralne, osobiste, prywatne życie" ${ }^{\text {44 }}$. Przykład Greków może się zatem okazać inspirujący dla tych, którzy pragnąc wyzwolenia, nie wiedzą, na jakiej zasadzie mogliby oprzeć nową etykę ${ }^{45}$.

\section{IV}

Namysł nad sposobami, w jakie istoty ludzkie przekształcają same siebie w podmioty, zdominował ostatnie lata twórczości Foucaulta. W tym czasie powstały prace, które ostatecznie ukazały się jako drugi i trzeci tom Historii seksualności (czyli odpowiednio Użytek z przyjemności oraz Troska o siebie). Temat seksualności, choć wydaje się tematem wiodącym, jest w nich tłem oraz pretekstem do ukazania możliwości podmiotowotwórczej pracy nad sobą. W jednym z wywiadów Foucault stwierdza wprost, że seks jest nudny i że o wiele bardziej interesuje go coś, co określa mianem „technik siebie”46. Wyjaśnia również, że jego Historię seksualności należałoby odczytywać jako zarazem historię moralności i genealogię etyki ${ }^{47}$. Chciał w niej bowiem pokazać, właśnie na przykładzie stosunku do seksu, że podczas gdy kodeksy moralne (określające to, co dozwolone i co zakazane) nie różniły się aż tak bardzo w czasach greckich, chrześcijańskich i nowożytnych, etyka, ujmowana przezeń jako relacja z samym sobą, ulegała istotowym przemianom.

\footnotetext{
41 Ibidem, s. 343 n.

42 B. Seitz, Foucault and the Subject of Stoic Existence, „Human Studies” 35 [4] (2012), s. 548.

${ }^{43}$ M. Foucault, On the Genealogy..., s. 343 n.

${ }^{44}$ Ibidem.

45 Ibidem.

46 Ibidem, s. 229-252.

47 Ibidem, s. 252, 256.
} 
Etyka jest według Foucaulta tą częścią moralności, która określa, „w jaki sposób jednostka powinna ukonstytuować się jako moralny podmiot swych własnych zachowań"48. Wyróżnia on cztery główne aspekty tak rozumianej etyki: substancję etyczną, to znaczy tę część siebie, która zostaje uznana za właściwą domenę moralnego zachowania i etycznego osądu; sposób ujarzmiania, czyli sposób, w jaki jednostka ustanawia swój stosunek do moralnych zobowiązań oraz zasad; pracę etyczną czy tė̇ praktykę siebie, którą wykonuje ona na samej sobie, by przekształcić się w etyczny podmiot; i wreszcie telos, czyli ten sposób bycia, który pragnie osiągnacc ten, kto postępuje etycznie ${ }^{49}$. Foucault uważał, że historia (czy też historie) moralności nie powinna skupiać się wyłącznie na dziejach moralnych kodeksów, że powinniśmy również badać różne formy moralnego upodmiotawiania — to, w jaki sposób konstytuujemy samych siebie jako moralne podmioty naszego własnego działania ${ }^{50}$.

W późniejszych tekstach ${ }^{51}$ Foucault wiąże rozważania dotyczące etyki z takimi kwestiami (także wzajemnie powiązanymi), jak „troska o siebie”, „kultura siebie”, „style egzystencji” czy „estetyka egzystencji”. Zależność ta jest oczywista, jeśli weźmiemy pod uwagę, że choć zarówno kodeks zachowań, jak i formy subiektywizacji są niezbędnymi elementami każdej moralności, to nie zawsze proporcje między nimi są równe, a tam, gdzie „etyka” wyraźnie przeważa nad „kodeksem”, troska o jakość własnego istnienia staje się głównym punktem odniesienia ${ }^{52}$.

Ponieważ domena moralności jest określana głównie przez nakazująco-zakazujące zasady, których zadaniem jest regulowanie różnorodnych zachowań i które od jednostki wymagają przede wszystkim posłuszeństwa, najważniejszą kwestią moralną staje się prawomocność owych zasad oraz skuteczność w ich egzekwowaniu. Niemniej jednak skuteczność ta zależy od tego, czy i do jakiego stopnia jednostka zdoła przekształcić samą siebie w moralny podmiot, którego sposób bycia i postępowania jest możliwie zgodny z określanymi przez kodeks regułami. Zatem również wtedy, gdy mamy do czynienia z moralnością zdominowaną przez kodeks, wymaga ona upodmiotowienia; jest to jednak upodmiotowienie szczególnego rodzaju — takie, które „dokonuje się zasadniczo w formie quasi-jurydycznej, gdzie podmiot moralny określa się wobec prawa lub zespołu praw, którym winien podporządkować się w obawie przed występkiem, zagrożonym karą"

Prawa, na których opiera się „moralność kodeksu”, mają charakter ponadjednostkowy, wywodzone z nich reguły są jednakowe dla wszystkich. Oczekuje się tutaj, że sposób istnienia i postępowania każdego będzie możliwie zgodny z powszechnie obowiązującym wzorcem. Ponieważ właśnie owa zgodność jest zasadniczym celem

48 Ibidem, s. 238.

49 Ibidem, s. 238-239. Por. M. Foucault, Historia..., s. 165-167.

50 M. Foucault, Historia..., s. 164-165.

${ }^{51}$ Wśród najważniejszych należy wymienić: drugą oraz trzecią część Historii seksualności (Użytek z przyjemności i Troska o siebie); cykl wykładów opublikowany jako Hermeneutyka podmiotu (tłum. M. Herer, Warszawa 2012), wywiad zatytułowany Return of Morality (w: Politics, Philosophy...) oraz cytowane wyżej On the Genealogy of Ethics i Czym jest Oświecenie?

${ }^{52}$ M. Foucault, Historia..., s. 168-169.

${ }^{53}$ Ibidem, s. 168. 
moralnym, taki, a nie inny kształt oraz jakość egzystencji poszczególnych jednostek nie jest uznawany za wartościowy i pożądany sam w sobie. Oznacza to też, że jego osiągnięcie nie musi być rezultatem świadomego wyboru, że jednostka może i powinna być doń nakłaniana, a nawet przymuszana z zewnątrz. Co więcej, nawet jeśli mamy do czynienia $\mathrm{z}$ wyborem, również on jest $\mathrm{z}$ góry przesądzony, $\mathrm{w}$ tym mianowicie sensie, że tylko jeden wybór może być właściwy, gdyż każdy inny oznaczałby wykroczenie przeciwko moralnemu prawu.

\section{V}

Opracowanie własnego życia jako osobistego dzieła sztuki, nawet jeśli było ono posłuszne pewnym kolektywnym regułom, stało w centrum [...] moralnego doświadczenia, moralnej woli w starożytności. Natomiast w chrześcijaństwie, z jego religia Pisma, ideą woli Boga i zasadą posłuszeństwa, moralność coraz bardziej przybierała formę kodeksu reguł (jedynie pewne praktyki ascetyczne praktyki były bardziej związane z ćwiczeniem osobistej wolności). [...] Przechodząc od starożytności do chrześcijaństwa, przechodzimy od moralności, która zasadniczo była poszukiwaniem osobistej etyki, do moralności jako posłuszeństwa systemowi reguł. A jeśli interesowałem się starożytnością, to dlatego że — z szeregu przyczyn idea moralności jako posłuszeństwa kodeksowi reguł jest obecnie w zaniku. Z tą nieobecnością moralności koresponduje, musi korespondować, poszukiwanie estetyki istnienia ${ }^{54}$.

Przeniesienie akcentu z kodeksu na zabiegi koło siebie, właściwe niektórym rodzajom moralności, sprawia, że najważniejsze dla jednostki staje się nie tyle ścisłe przestrzeganie reguł, ile spełnianie wymogów związanych z nadawaniem odpowiedniego kształtu własnemu istnieniu. Konieczne jest tutaj osiągnięcie zdolności do poznawania samego siebie, kontrolowania, doskonalenia się oraz samoprzemiany ${ }^{55}$. Odwrotnie zatem niż w ,moralności nakierowanej na kodeks” kształt i jakość indywidualnego istnienia stają się właściwym celem (stąd określenie „estetyka egzystencji”), przestrzeganie zaś reguł jest istotne przede wszystkim ze względu na to, iż pozwala lepiej panować nad sobą i samego siebie przekształcać. I tak, powiada Foucault, w refleksji moralnej starożytności greckiej czy grecko-rzymskiej

akcent pada na stosunek jednostki do siebie, pozwalający jej nie ulegać porywom zachcianek i przyjemności, zachowywać wobec nich opanowanie i przewagę, utrzymywać swoje zmysły w równowadze, pozostawać wolnym wobec wszelkiego wewnętrznego niewolnictwa żądzy i zmierzać ku sposobowi bycia, który można uznać za rozkoszowanie się sobą bądź doskonałe zwierzchnictwo samego siebie nad sobą ${ }^{56}$.

Biorąc pod uwagę wymagania, jakim musi sprostać troszcząca się o siebie jednostka, należy zgodzić się z Foucaultem, że ten rodzaj moralności jest, a na pewno może być, surowszy aniżeli moralność ukierunkowana na kodeks. Funkcja, jaką pełnią w niej zawarte w kodeksie reguły, pozwala też zrozumieć, dlaczego pomi-

\footnotetext{
${ }^{54}$ M. Foucault, An Aesthetics..., s. 49.

55 M. Foucault, Historia..., s. 167.

56 Ibidem, s. 169-170.
} 
mo występowania zasadniczo odmiennych form subiektywizacji sam kodeks mógł trwać we względnie niezmienionej postaci.

Mając to na uwadze, możemy dookreślić sens sformułowanego przez Foucaulta wezwania do moralnej przemiany. Nie chodzi w nim o obalanie dotychczasowych i ustanawianie nowych zespołów wartości i reguł postępowania. Uważa on bowiem, że materią samokreacji mogą być wyłącznie już istniejące praktyki:

podmiot jest konstytuowany przez praktyki ujarzmiania lub też, w bardziej autonomiczny sposób, przez praktyki uwalniania się, praktyki wolności, tak jak w starożytności, oczywiście w oparciu o szereg reguł, stylów i innowacji, które można odnaleźć w środowisku kulturowym ${ }^{57}$.

Twórczy podmiot nie jest wolny od społecznego wpływu, ale będąc twórczym, jest w stanie wpływ ten ukierunkowywać i kształtować, oprzeć się wszechobecnej presji na normalizację i uczynić swoje istnienie czymś autentycznie własnym, wyjątkowym.

Nie jest możliwe, by ktokolwiek zdołał wykroczyć poza normalizujący wpływ władzy. I choć systemy czy tė sieci władzy nie są wieczne i ulegają, niejednokrotnie fundamentalnym, przekształceniom, nikt nie jest w stanie ich kontrolować czy decydować o ich kształcie. A jednak, jak pisze jeden z komentatorów myśli Foucaulta,

wiemy z historii, że przynajmniej w niektórych przypadkach istoty ludzkie zdołały wynaleźć i rozwinąć sposoby przekształcania jaźni, którymi stały się wskutek działania konstytuujących ich sieci władzy/ wiedzy. Tym właśnie zajmował się Foucault, kiedy badał askesis starożytnych, ich techne tou biou. [...] Te starożytne praktyki samokształtowania się, troski o siebie, pokazują, że istoty ludzkie są w stanie nadawać własnemu istnieniu określony kształt, formę podmiotowości. Ujawniają możliwość świadomej twórczej przemiany czy nawet tego, co Foucault nazywa sztuką życia ${ }^{58}$.

Tym, co naprawdę istotne, jest zmiana w sposobie ustosunkowywania się do samego siebie, czyli odmienne niż dotychczas wykorzystywanie istniejących w kulturowej przestrzeni wartości i reguł po to, by konstytuować siebie jako podmiot moralny. Foucault uważa, że zmiana ta jest potrzebna, że powinniśmy zacząć szukać możliwości uprawiania estetyki istnienia, ponieważ idea moralności jako posłuszeństwa wobec określonych zasad, nadal utożsamiana przez nas z moralnością jako taką, jest $\mathrm{w}$ dzisiejszych czasach $\mathrm{w}$ zaniku ${ }^{59}$. A dzieje się tak między innymi dlatego, iż wydaje się ona niezgodna z ideą samosterownego podmiotu, będącego centrum myślenia i działania, do której tak mocno jesteśmy przywiązani. Jednak wolność ta to według Foucaulta iluzja, która maskuje rzeczywisty obraz i pochodzenie naszej tożsamości, narzuconego nam wytworu procesów ujarzmiania dokonujaccych się w obrębie sieci relacji władzy. Praktykowanie troski o siebie ma na

${ }^{57}$ M. Foucault, An Aesthetics..., s. 50-51. „Również twórczość jest zawsze historycznie usytuowana. Nie wszystko jest możliwe w dowolnym czasie. Jak każdy inny, artyści muszą pracować w obrębie ograniczeń swych własnych tradycji. Twórczość polega na przearanżowywaniu tego, co już jest; innowacja wymaga manipulowaniu tym, co dane. Życie, ujmowane estetycznie, nie jest inne; artystyczna kreacja samego siebie [...] musi z konieczności używać tworzywa, które zawsze jest już obecne" — A. Nehemas, The Art. Of Living. Socratic Reflections from Plato to Foucault, Berkeley 2000, s. 178.

${ }^{58}$ L. MacWhorter, Subjecting Dasein, [w:] Foucault and Heidegger. Critical Encounters, A. Milchman, A. Rosenberg (red.), Minneapolis 2003, s. 123.

59 M. Foucault, An Aesthetics..., s. 49. 
celu osiągnięcie całkowicie innego rodzaju wolności, „doskonałego zwierzchnictwa samego siebie nad sobą”, które pozwala „pozostawać wolnym wobec wszelkiego wewnętrznego niewolnictwa żądzy". Ale ktoś, kto osiągnął panowanie nad sobą, jest kimś innym aniżeli ten, kto uczynić tego nie chciał lub nie zdołał. Zakłada ono bowiem transformację samego siebie, określenie siebie na nowo i kształtowanie zgodne z tym określeniem. W efekcie nadajemy własnemu istnieniu niepowtarzalny styl, coś, co pozwala nam „rozkoszować się sobą”:

Fascynuje mnie idea bios jako materiału dla estetycznego dzieła sztuki. Również idea, że etyka może stanowić bardzo silną konstrukcję egzystencji, niepozostającą w żadnej relacji z tym, co jurydyczne per se, z jego autorytarnym systemem, z dyscyplinarną strukturą ${ }^{60}$.

Kiełznanie i formowanie życia poprzez strategie i techniki władzy nie jest jedynym sposobem jego kształtowania; tak jak działanie władzy dyscyplinarnej nie jest jedynym sposobem dyscyplinowania. Możliwa jest twórcza samodyscyplina praktykowana jako estetyka egzystencji („Czy życie każdego z nas nie mogłoby stać się dziełem sztuki? Dlaczego artystycznym przedmiotem może być lampa czy dom, ale nie nasze życie?"61). Foucault wskazuje na przykład etyki stoików, która jego zdaniem nie miała nic wspólnego z normalizacja, ponieważ jej zasadniczy cel był właśnie estetyczny — była osobistym wyborem tych niewielu ludzi (elity), którzy pragnęli „,wieść piękne życie oraz pozostawić innym pamięć pięknej egzystencji”62. Stoicy nie dążyli tego, by ten sam wzorzec życia i postępowania odnosić do wszystkich, nie pragnęli narzucać go każdemu, określać z góry, kim każdy być powinien. Nie oznacza to jednak, że ich moralny kodeks zakazywał mniej i nie był tak rygorystyczny jak na przykład kodeks moralności chrześcijańskiej. W obu przypadkach asceza była środkiem do osiągnięcia celu, lecz sam cel był pojmowany całkowicie odmiennie. Z kolei zawarte w kodeksach normy, oraz rozmaite sposoby ich realizacji, są elementami środowiska kulturowego, niezbędnego punktu odniesienia dla wszystkich sposobów konstytuowania podmiotowości. (Nieliczni) Grecy i Rzymianie czynili to w sposób, który — jak sądzi Foucault — mógłby dopomóc nam w uwolnieniu się ze skonstruowanej przez aparaty władzy klatki tożsamości.

\section{Bibliografia}

Bernauer J., Mahon M., Michel Foucault's Ethical Imagination, [w:] The Cambridge Companion to Foucault, G. Gutting (red.), Cambridge-New York 2005, s. 149-175.

Bevir M., Foucault and Critique: Deploying Agency against Autonomy, „Political Theory" 27 [1] (1999), s. 65-84.

Foucault M., Two Lectures, [w:] Power/Knowledge: Selected Interviews and Other Writings 1972-1977, C. Gordon (red.), Brighton 1980, s. 78-108.

\footnotetext{
60 Ibidem, s. 348 .

61 Ibidem, s. 350.

62 Ibidem, s. 341.
} 
Foucault M., On the Genealogy of Ethics: An Overview of Work in Progress, [w:] Foucault: Beyond Structuralism and Hermeneutics, H. Dreyfus, P. Rabinow (red.), Chicago 1983, s. 229-252.

Foucault M., An Aesthetics of Existence, [w:] Michael Foucault: Politics, Philosophy, Culture: Interviews and Other Writings 1977-1984, L. Kritzman (red.), London1988, s. 47-53.

Foucault M. Return of Morality, [w:] Michael Foucault: Politics, Philosophy, Culture: Interviews and Other Writings 1977-1984, L. Kritzman (red.), London 1988, s. $242-254$.

Foucault M., Historia seksualności, tłum. B. Baran, T. Komendant, K. Matuszewski, Warszawa 1995.

Foucault M., Czym jest Oświecenie?, [w:] idem, Filozofia, historia, polityka. Wybór pism, tłum. D. Leszczyński, L. Rasiński, Warszawa 2000.

Foucault M., „Omnes et singulatim”: przyczynek do krytyki politycznego rozumu, [w:] idem, Subject and Power, w: idem, Power. Essential Works of Foucault, t. 3, J. Faubion (red.), New York 2001, s. 208-226.

Foucault M., Truth and Juridical Forms, [w:] idem, Power. Essential Works of Foucault, t. 3, J. Faubion (red.), New York 2001, s. 1-89.

Foucault M., Society must be defended, tłum. D. Macey, New York 2003.

Foucault M., Hermeneutyka podmiotu, tłum. M. Herer, Warszawa 2012.

Hindess B., Filozofie władzy Od Hobbesa do Foucaulta, tłum. D. Leszczyński, L. Rasiński, Warszawa-Wrocław 1999.

Nehemas A., The Art. Of Living. Socratic Reflections from Plato to Foucault, Berkeley 2000.

MacWhorter L. Subjecting Dasein, [w:] Foucault and Heidegger. Critical Encounters, A. Milchman, A. Rosenberg (red.), Minneapolis-London 2002, s. 176-294.

Seitz B., Foucault and the Subject of Stoic Existence, „Human Studies” 35 [4] (2012), s. $539-554$.

Thiele L., Foucault's Triple Murder and the Modern Development of Power, „Canadian Journal of Political Science / Revue canadienne de science politique" 19 [2] (1986), s. $243-260$. 